\title{
TEKNIK PENGOPERASIAN DAN PENANGKAPAN IKAN BAUNG (Mystus nemurus) DAN IKAN LAIS (Kryptopterus apogon) DENGAN MENGGUNAKAN PANCING RAWAI (LONG LINES) DI DANAU TELUK GELAM, KABUPATEN OGAN KOMERING ILIR, SUMATERA SELATAN
}

\author{
Muhtarul Abidin \\ Teknisi Litkayasa pada Balai Riset Perikanan Perairan Umum, Mariana-Palembang
}

Teregristasi I tanggal: 15 Juni 2006; Diterima setelah perbaikan tanggal: 2 Maret 2007; Disetujui terbit tanggal: 2 Mei 2007

\section{PENDAHULUAN}

Danau Teluk Gelam terletak di Desa Mulyaguna (Bunut) Kecamatan Tanjung Lubuk Kabupaten Ogan Komering Ilir Propinsi Sumatera Selatan. Di danau ini terdapat banyak jenis-jenis ikan antara lain ikan toman (Channa micropeltes), gabus (Channa striata), sepat siam (Trychogaster pectoralis), sepat mato merah (Trichogaster trichopterus), tambakang (Helostoma temmincki), lais (Kryptopterus apogon), dan ikan baung (Mystus nemurus).

Usaha penangkapan ikan baung dan lais di Danau Teluk Gelam menggunakan pancing rawai yang diberi umpan kucur (merupakan sejenis umpan yang mempunyai bau busuk yang khas hasil fermentasi). Rawai yang dioperasikan menggunakan ukuran mata pancing yang bervariasi No.7 ukuran kecil $1.001 \mathrm{~B}$ dan yang besar No.5 ukuran 1.054 BN terbuat dari bahan carbon (carbon inox fishing hook). Dan sebagai pelengkap digunakan tali cabang (brane line) yang diikatkan pada tali utama (mine line). Tali utama terbuat dari bahan polyethilen dan tali cabang terbuat dari bahan monofilament $12 \mathrm{lb} 0,75 \mathrm{~mm}$ dan $10 \mathrm{lbs}$ 0,23 mm. Menurut Koike \& Takeuchi (1970), tingkat efisiensi penangkapan dengan alat tangkap pancing untuk jenis ikan tertentu ditentukan oleh besar ukuran mata pancing yang digunakan.

Berdasarkan pada hal tersebut di atas, maka penulisan ini bertujuan untuk menyajikan tentang cara pengoperasian dan cara penangkapan dengan menggunakan pancing rawai yang berbeda ukuran untuk menangkap ikan baung dan lais di Danau Teluk Gelam Ogan Komering llir, Sumatera Selatan.

\section{BAHAN DAN METODE}

Bahan terdiri atas:

1. Polyethilen diameter $0,5 \mathrm{~cm}$ (tali utama).

2. PA monofilamen diameter $0,23 \mathrm{~cm}$ (tali cabang).

3. Mata pancing ukuran 1.054 BN dan $1.001 \mathrm{~B}$.

4. Kawat monel dan kili-kili.
5. Pelampung dengan diameter 10 sampai dengan $15 \mathrm{~cm}$ dan panjang 25 sampai dengan $30 \mathrm{~cm}$.

6. Kayu tonggak atau pancang.

7. Pemberat (batu cetak ikuran $10 \times 10 \mathrm{~cm}$ ).

Alat terdiri atas perahu dan perlengkapan.

\section{Spesifikasi Alat dan Cara Pembuatan}

\section{Perahu}

Untuk mengoperasikan rawai diperlukan sebuah perahu dengan ukuran panjang $6 \mathrm{~m}$, lebar $1,5 \mathrm{~m}$, dan dalam 50 sampai dengan $60 \mathrm{~cm}$, dan dilengkapi dengan pendayung di mana bahan terbuat dari kayu dengan diameter 3 sampai dengan $5 \mathrm{~cm}$, panjang 50 sampai dengan $100 \mathrm{~cm}$, dan dioperasikan oleh 3 orang, 1 orang sebagai pengendali keseimbangan perahu dan 2 orang sebagai pemasang atau tenaga setting rawai.

\section{Rawai (Long Lines)}

Untuk membuat dan setting rawai diperlukan bahan-bahan pembuat rawai seperti tali utama (main lines) yang terbuat dari bahan polyethilen $\varnothing 0,5 \mathrm{~cm}$, panjang 20 sampai dengan $30 \mathrm{~m}$, dan tali cabang (brane lines) dari bahan PA monofilament $\varnothing 0,23$ dan $0,35 \mathrm{~mm}$ panjang 50 sampai dengan $100 \mathrm{~cm}$. Sebagai pelengkap tali cabang diperlukan mata pancing 20 sampai dengan 30 buah per rawai atau per raban (istilah yang dipakai untuk mengatakan 1 rawai) dengan ukuran 1.054 BN untuk pancing No.5 dan ukuran 1.001 B untuk mata pancing No.7. Jarak tali cabang satu dengan yang lain berjarak $50 \mathrm{~cm}$, dan untuk mata pancing sebelum diikatkan pada tali cabang terlebih dahulu dihubungkan atau diikatkan pada kawat monel dan kili kili panjang 5 sampai dengan $10 \mathrm{~cm}$ dari pangkal mata pancing. Tujuan supaya pancing tidak terputus saat dimakan ikan. Untuk menyesuaikan tenggelam tali cabang saat dipasang dipakai pelampung berbentuk bulat panjang dengan ukuran panjang 25 sampai dengan $30 \mathrm{~cm}$ dan berdiameter 10 sampai dengan $15 \mathrm{~cm}$ jumlah 10 buah, 
dipasang dengan jarak $3 \mathrm{~m}$ antara pelampung satu dengan yang lain, dan diikatkan pada tali utama, sedangkan kayu tonggak diperlukan untuk tempat mengikat pada ujung dan pangkal tali utama. Tujuan supaya rawai tidak hanyut terbawa angin atau ketika rawai dimakan ikan juga untuk memudahkan ketika memberi umpan dan tali cabang tidak kusut atau berbelit saat dipasang. Dan pemberat dibuat dari batu yang dicetak dengan ukuran $10 \times 10 \mathrm{~cm}$ diikatkan pada tali yang dihubungkan dengan tali utama. Tujuan supaya rawai tidak hanyut terbawa arus air saat di pasang atau dioperasikan (Gambar 1).

\section{Mata Pancing (Hook)}

Mata pancing yang digunakan terbuat dari carbon (high carbon inox fishing hook) No.5 (1.054 BN) dan No.7 (1.001 B). Adapun spesifikasi ukuran mata pancing digunakan seperti pada Tabel 1.
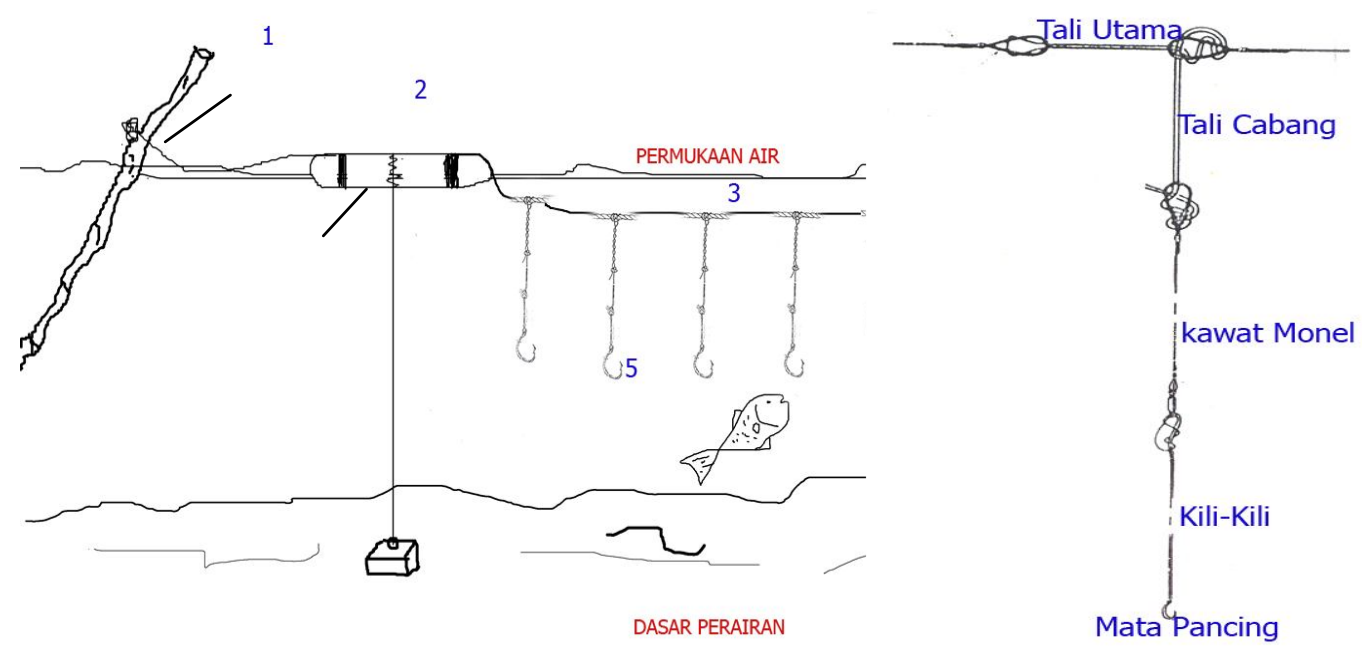

Gambar 1.

Rancang bangun rawai (long lines).

Keterangan: 1. Kayu pancang; 2. Pelampung; 3. Tali utama (main lines);

4. Tali cabang (brane lines); 5. Mata pancing; 6 . Pemberat

Tabel $1 . \quad$ Spesifikasi mata pancing rawai

\begin{tabular}{|c|c|c|}
\hline Spesifikasi & $\begin{array}{c}\text { Mata pancing } \\
\text { No.5 }\end{array}$ & $\begin{array}{c}\text { Mata pancing } \\
\text { No.7 }\end{array}$ \\
\hline Tinggi (length) $\mathrm{cm}$ & 2,0 & 1,0 \\
\hline Lebar (width) $\mathrm{cm}$ & 1,0 & 0,6 \\
\hline Pengait pancing (barb) $\mathrm{cm}$ & 1,0 & 0,5 \\
\hline
\end{tabular}

\section{Cara Pengoperasian}

\section{Rawai (Set Long Lines)}

Untuk mengoperasikan rawai digunakan perahu kayu dengan tenaga operasional saat pemasangan rawai adalah 3 orang, 1 orang bertugas sebagai pengendali keseimbangan perahu dan 2 orang bertugas sebagai penyetelan rawai.

Rawai dipasang atau dioperasikan memotong atau melintang di pinggir atau di tengah perairan, dengan mengikatkan tali utama baik pada bagian ujung dan pangkal tali utama pada kayu tonggak atau pancang yang sudah disiapkan, guna untuk memudahkan menyusun rawai saat pemasangan juga untuk menghindari tali cabang kusut atau berbelit, dan pemasangan rawai disesuaikan dengan kedalaman perairan setempat. Setelah setting rawai selesai, dan sebagai daya tarik ikan sasaran, maka pancing diberi umpan. Dalam hal ini, umpan yang dipakai adalah Kucur (nama sejenis umpan ikan yang mampunyai bau busuk yang khas hasil fermentasi). Untuk memperoleh hasil tangkapan yang banyak rawai dipasang pada malam hari dimulai dari sore hari dan diangkat pada pagi hari (Gambar 2). 


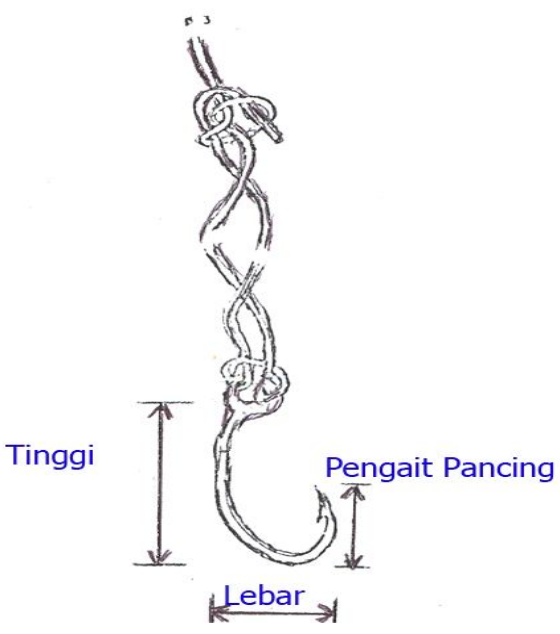

Gambar 2. Spesifikasi mata pancing rawai.

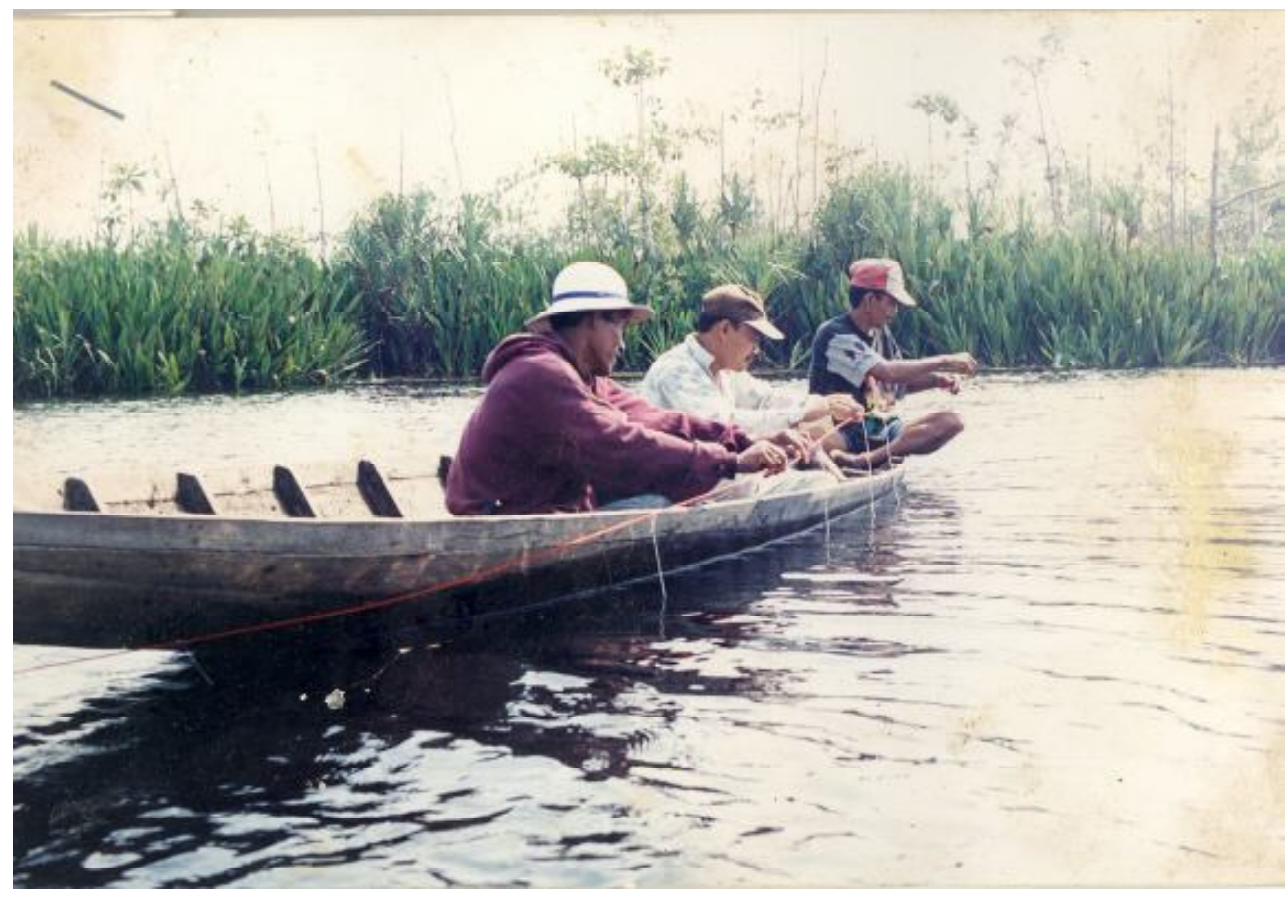

Gambar 3. Pemasangan rawai di Danau Teluk Gelam, Ogan Komering Ilir Sumatera Selatan.

\section{HASIL DAN BAHASAN}

\section{Hasil Tangkapan}

Menurut Wudianto et al. (1995), mata pancing yang berukuran kecil lebih efektif untuk menangkap ikan dibanding mata pancing yang berukuran lebih besar. Hal ini, dikuatkan dari hasil tangkapan pancing rawai bahwa pancing rawai ukuran kecil banyak dimakan ikan ukuran besar maupun ukuran kecil, untuk jenis ikan seperti ikan baung dan lais. Namun, dari hasil tangkapan yang diperoleh dari pengoperasian pancing rawai dengan mata pancing No.5 dan 7 memberikan gambaran bahwa pancing ukuran besar, dimakan oleh ikan ukuran besar (Tabel 2). Hal ini, sesuai pendapat Koike \& Takeuchi (1970), bahwa tingkat efisiensi penangkapan dengan alat tangkap pancing untuk jenis ikan tertentu ditentukan oleh besar ukuran mata pancing yang digunakan. Dan dari hasil tangkapan yang dominan tertangkap adalah jenis ikan karnivora seperti ikan baung (Mystus nemurus) dan jenis ikan lain seperti ikan lais muncung (Kryptopterus apogon). 
Tabel 2. Hasil tangkapan rata-rata ikan baung dan lais dengan menggunakan pancing rawai No.5 dan 7 di Danau Teluk Gelam Ogan Komering Ilir, Sumatera Selatan

\begin{tabular}{lccccc}
\hline \multirow{2}{*}{ Jenis ikan } & \multicolumn{2}{c}{ Mata pancing No.5 } & \multicolumn{2}{c}{ Mata pancing No.7 } & Keterangan \\
\cline { 2 - 5 } & $\begin{array}{c}\text { Panjang } \\
\text { ikan (cm) }\end{array}$ & $\begin{array}{c}\text { Bobot } \\
\text { ikan (g) }\end{array}$ & $\begin{array}{c}\text { Panjang } \\
\text { ikan (cm) }\end{array}$ & $\begin{array}{c}\text { Bobot } \\
\text { ikan (g) }\end{array}$ & \\
\hline $\begin{array}{c}\text { 1. Baung } \\
\text { (Mystus nemurus) }\end{array}$ & 37,5 & 551 & 29,1 & 270 & $\begin{array}{c}\text { Semakin kecil nomor } \\
\text { pancing, maka semakin } \\
\text { besar ukuran mata } \\
\text { pancing (Tabel 1) }\end{array}$ \\
$\begin{array}{c}\text { 2. Lais } \\
\text { (Kryptopterus apogon) }\end{array}$ & 26,0 & 95,0 & 21,0 & 50,0 & \\
\hline
\end{tabular}

\section{KESIMPULAN}

Ukuran mata pancing memberikan gambaran besar kecil ikan yang tertangkap, semakin besar mata pancing kemungkinan ikan yang tertangkap lebih besar. Begitu pula cara pemasangan dan jenis umpan memberikan kontribusi terhadap hasil tangkapan.

\section{DAFTAR PUSTAKA}

Koeke, A. \& S. Takeuchi. 1970. Selection curve of the hook of pole fishing. Journal Tokyo. University Fisheries. Vol.57 (1): 1-7.

Wudianto, Mahiswara, \& M. Linting. 1995. Pengaruh ukuran mata pancing rawai dasar terhadap hasil tangkapan. Jurnal Penelitian Perikanan Indonesia. Vol.1 (1): 38-67. 